\title{
The hematological profile of Barbonymus altus to evaluate water quality in the Badher Bank Conservation Area, Blitar, East Java, Indonesia
}

\author{
ASUS MAIZAR SURYANTO HERTIKA", SUPRIATNA, ARIEF DARMAWAN, BIMO AJI NUGROHO, \\ AGUNG DWI HANDOKO, AGUSTIANSI YEYEN QURNIAWATRI, RANITA AYU PRASETYAWATI \\ Department of Aquatic Resource Management, Faculty of Fisheries and Marine Science, Universitas Brawijaya. Jl. Veteran, Lowokwaru, Malang 65145, \\ East Java, Indonesia. Tel./fax.: +62-341-551611, `email: asusmaizar@ub.ac.id
}

Manuscript received: 30 January 2021. Revision accepted: 12 April 2021.

\begin{abstract}
Hertika AMS, Supriatna, Darmawan A, Nugroho BA, Handoko AD, Qurniawatri AY, Prasetyawati RA. 2021. The hematological profile of Badher fish (Barbonymus altus) to evaluate water quality in the Badher Bank Conservation Area, Tawangrejo Village, Blitar District, East Java, Indonesia. Biodiversitas 22: 2532-2541. Badher fish (Barbonymus altus) is endemic to the Brantas River. After years presumably extinct, the Badher fish was found again in 2010 in the Brantas River, Tawangrejo Village, Binangun Subdistrict, Blitar District, East Java, Indonesia. A conservation area, called a Badher Bank, was established in the location. However, human activities, such as ecotourism and agricultural waste runoff, have changed water quality and increased water pollution in the Badher Bank Conservation Area. This research objective was to observe the hematological profile of badher fish and a set of water quality parameter measurements as an environmental factor that affected fish life. Data were obtained from four research stations with three replications every two weeks from August to October 2020 at the Brantas River streamline inside the Badher Bank Conservation Area. The Canonical Correspondence Analysis (CCA) method was applied to determine the correlation between water quality and hematological profile. According to the data analysis, the water quality at Stations 1-3 in the research location was normal, and Station 4 was polluted. The analysis also showed that the low dissolved oxygen and high ammonia affected the hematological conditions of Badher fish. All water quality parameters affected the condition of leucocytes, erythrocytes, and hemoglobin in moderate concentrations. Besides that, micronuclei and hematocrit conditions were strongly influenced by ammonia, temperature, $\mathrm{pH}$, and current velocity in high concentrations, while Dissolved Oxygen (DO) and Total Suspended Solid (TSS) affected low concentrations.
\end{abstract}

Keywords: Badher Bank, Badher fish, Barbonymus altus, hematological profile, water pollution, water quality

\section{INTRODUCTION}

The Brantas River that passing through Blitar District is a part of Brantas Watershed. It has been determined as one of the national priorities and the most critical watershed (Decree of the Minister of Public Works and Housing Number 268 of 2010; Jariyah 2019). The river has high potential fish resources and must be conserved. One of the endemic fish in the Brantas River is the Badher fish (Barbonymus altus). The Badher fish is characterized by red fins (Haryono et al. 2017). After years of disappearing and presumably extinct, the Badher fish was found again in 2010 in the Brantas River, Tawangrejo Village, Binangun Sub-district, Blitar District by Kelompok Masyarakat Pengawas (Pokmaswas) Fajar Bengawan, a community group aiming at supervising, empowering, and managing natural potentials in coastal and marine areas. Then, Pokmaswas Fajar Bengawan established a conservation area over the river for the Badher fish. The conservation area was booming in 2014. It turned into ecotourism "Omah Iwak Badher Bank" and was signed up as a tourist destination in the tourist village program managed by Kelompok Sadar Wisata (Pokdarwis), a local institution consisting of tourism actors who have the concern and responsibility to ensure the implementation and management of tourism villages. Nowadays, "Omah Iwak Badher Bank" held more activities not only conservation but also workshops, competency certifications, meetings, and study tours.

Land-use change and agricultural activities surrounding the conservation area increased the runoff, then affected the water quality of the Brantas River. Based on primary land use data (2020), "Omah Iwak Badher Bank's" surrounding area is dominated by rice fields and plantations as such, water quality may reduce because of agricultural waste runoff such as unionized ammonia. The runoff from inland agriculture containing urea is relatively large and seeps through the soil into the river bodies (Azizah and Humairoh 2015). Besides that, fish feeding inside the conservation area also contributes to decreasing water quality. Law Number 5 of 1990 clearly stated that people are prohibited from carrying out activities inside the core zone of a conservation area that may change the core zone condition. Tourism activities must be carried out in the use zone. In contrast, fish feeding as one of the main tourist attractions, whose frequency depends on the number of visitors, can accumulate suspended solids in the core zone or even accumulate at specific points inside the conservation area waters. As a result, "Omah Iwak Badher Bank", as a "Badher Bank Conservation Area", encounters new threats due to ecotourism and agricultural waste runoff.

The threats have been contributing to water pollution and the reduction of water quality. Water in the Brantas River that passes through the conservation area is presumed to have low quality. Water pollution occurs when harmful 
substances or other components, primarily resulting from human activities, contaminated waters, leading to decreased water quality where the water can no longer serve its purpose (Government Regulation Number 82 of 2001). Jariyah (2019) stated a significant change in the land function happened along the Brantas Riverbank the lands have been changed into agriculture and tourism areas without considering the environmental aspects.

Based on these conditions, it is necessary to test the hematological profile of Badher fish and the water quality because it influences the fish' life. The hematological condition of Badher fish can change quite rapidly because their life is closely related to their habitat (Lestari et al. 2017). Hematological profiles include the total erythrocyte, leukocyte, hemoglobin, hematocrit, and micronuclei. The profiles can help evaluate fish's psychological conditions and the toxic stressors from the environment (Solleh et al. 2015). Therefore, this study aims to assess the hematological profile of the Badher fish and its correlation with water quality.

\section{MATERIALS AND METHODS}

\section{Study location}

This research was conducted along the Brantas River stream at "Omah Iwak Badher Bank", Tawangrejo Village,
Binangun Sub-district, Blitar District, East Java, Indonesia (Figure 1). Sampling was carried out at four stations (utilization zones and core zones) from the east (upstream) to west (downstream) of the Brantas River inside the conservation area. The four research stations are determined using a purposive sampling method, intentionally selected to consider land-use data of the Badher Bank Conservation Area. It was also conducted with three replications every two weeks from August to October 2020 for measurement accuracy.

Table 1. Method of measuring water quality parameter

\begin{tabular}{|c|c|c|}
\hline Parameter & Unit & Sampling method \\
\hline Temperature & ${ }^{\circ} \mathrm{C}$ & $\begin{array}{l}\text { Digital Oxygen Meter } \\
\text { Lutron PDO-520 }\end{array}$ \\
\hline $\mathrm{pH}$ & & Digital $\mathrm{pH}$ meter \\
\hline Dissolved Oxygen (DO) & $\mathrm{mg} / \mathrm{L}$ & $\begin{array}{l}\text { Automatic Calibration } \\
\text { Digital Oxygen Meter } \\
\text { Lutron PDO-520 }\end{array}$ \\
\hline Total Suspended Solid (TSS) & $\mathrm{mg} / \mathrm{L}$ & SNI 06-6989.3-2004 \\
\hline Unionized ammonia $\left(\mathrm{NH}_{3}\right)$ & $\mathrm{mg} / \mathrm{L}$ & SNI 19-7119.1-2005 \\
\hline Current Velocity & $\mathrm{m} / \mathrm{s}$ & SNI 8066:2015 \\
\hline
\end{tabular}

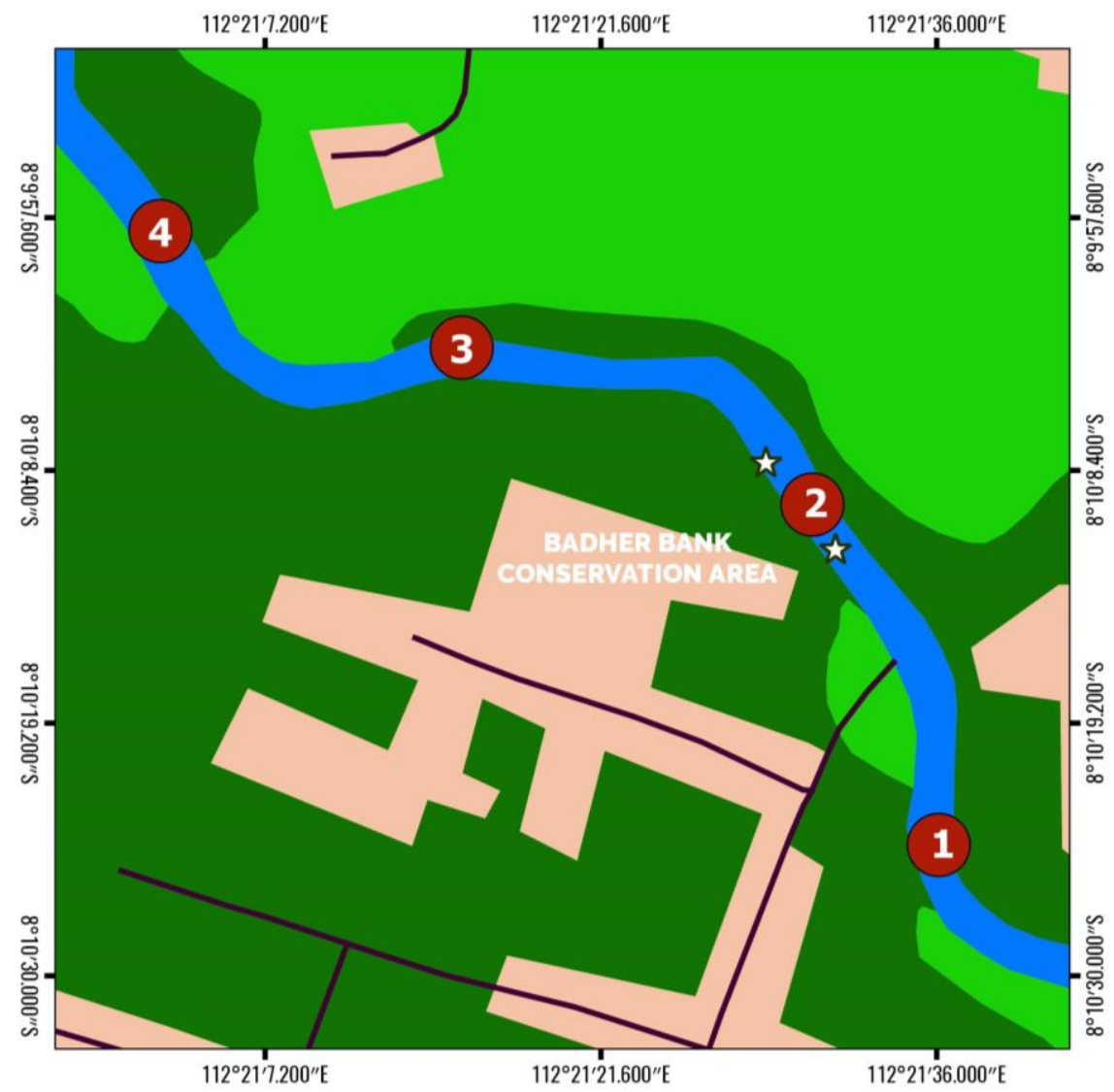

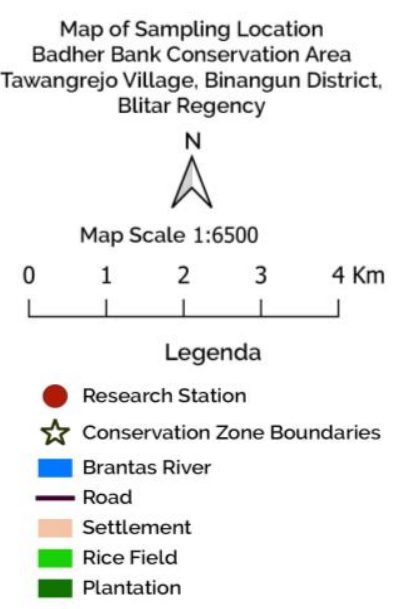
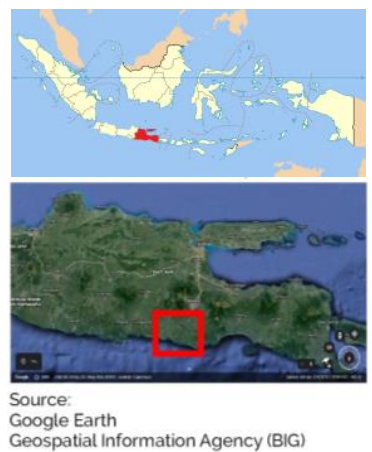

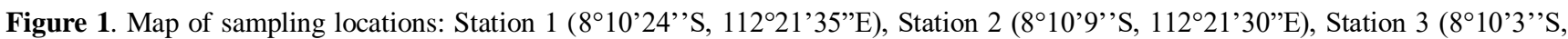
$\left.112^{\circ} 21^{\prime} 18^{\prime \prime} \mathrm{E}\right)$ and Station 4 (8'9'57'’S, 112 21'2'’E) 


\section{Methods}

Sample of water and laboratory method

Sample of water taken by using a set of cleaned polyethylene bottles, namely SA1-4. This procedure is according to Olasoji et al. (2019). After the bottles were full, they were transported to the laboratory using a coolbox that was already filled with ice cubes for further analysis at the Hydrobiology Laboratory, Division of Environment and Aquatic Biotechnology, Faculty of Fisheries and Marine Sciences, Brawijaya University, Malang, Indonesia. The Total Suspended Solid (TSS) and unionized ammonia $\left(\mathrm{NH}_{3}\right)$ were measured based on the SNI 06-6989.3-2004 and SNI 19-7119.1-2005 methods. The optimal water quality level refers to the Government Regulation Number 82 of 2001 concerning Water Quality Management and Water Pollution Control. Meanwhile, water quality parameters were measured directly on the site, such as $\mathrm{pH}$ measured using an Automatic Calibration Digital pH meter. On the other hand, the Dissolved Oxygen (DO) and temperature were measured using a Lutron PDO520 Digital Oxygen Meter. Lastly, the current velocity was measured using a conventional current meter referring to the Indonesian National Standards (SNI) 8066:2015.

\section{Fish blood sample}

Before Badher fish blood sampling was taken, the targeted fish was captured by using fishnet. A total of three fishes were caught per sampling location. Blood samples of Badher fish were obtained directly from the lateral line of the caudal fin of approximately $90 \mu \mathrm{L}$ using a $1 \mathrm{~mL}$ syringe containing $\pm 10 \mu \mathrm{L}$ sodium citrate anticoagulant. The blood was then transferred to $1.5 \mathrm{~mL}$ Eppendorf according to the sample name (DB1-9) and homogenized by referring to the method in Arfiati et al. (2020). After sampling of fish blood was completed, it was put into a cool-box with ice gels and immediately transported to the Laboratory of Parasites and Fish Diseases, Faculty of Fisheries and Marine Sciences, Brawijaya University, Malang, Indonesia.

\section{Hematological study}

Hematological parameter testing includes the total number of erythrocytes and leucocytes, hematocrit, hemoglobin, and micronuclei. Erythrocytes and leucocytes were tested using a hemocytometer (Priya et al. 2015; Nwani et al. 2016). Hemoglobin was tested using the cyanmethemoglobin method (Pawar and Bhilave 2019). Furthermore, hematocrit was tested using the microWestergren method (Yaji et al. 2018), and micronuclei were tested using the technique from Naqvi et al. (2016).

\section{Data analysis}

The correlation between water quality and blood profiles was analyzed using the CCA (Canonical Correspondence Analysis) method. CCA is a multivariate analysis that can explain the relationship between biological communities and environmental parameters in the form of ordination (Yüce and Gönülol 2016). CCA analysis was performed using the PAST software version 4.03. The CCA test was used to figure out the contribution of the independent variable to the dependent variable and to determine the most influencing parameters of the dependent variable (JiaXin et al. 2016). An independent variable is a stable variable and unaffected by the other variables, while a dependent variable depends on other factors measured. In this research, the independent variable was the water quality parameters. Meanwhile, the dependent variable was hematological profiles (including erythrocytes, leukocytes, hemoglobin, hematocrit, and micronuclei).

\section{RESULTS AND DISCUSSION}

\section{Water quality measurement results}

Figure 2 shows the temperature measurements at four stations carried out in the Badher Bank conservation area streamline. The temperature ranged from $27.3^{\circ}-30.7^{\circ} \mathrm{C}$ $\left(27.6^{\circ}-30.7^{\circ} \mathrm{C}\right.$ at Station 1 and $27.6^{\circ}-28.7^{\circ} \mathrm{C}$ at Station 2, $27.9^{\circ}-30.3^{\circ} \mathrm{C}$ at Station 3 , and $27.3^{\circ}-30^{\circ} \mathrm{C}$ at Station 4 ). The temperature increased at week two at all stations, yet there was relatively no difference between Stations 1 to 4 . The results of the current velocity at the research site ranged from 0.6 to $1 \mathrm{~m} / \mathrm{s}$. At Station 1 and 4 , the current velocity ranged from $0.6-1 \mathrm{~m} / \mathrm{s}$, at Station 2 , the current velocity went from $0.7-1 \mathrm{~m} / \mathrm{s}$. Meanwhile, the current velocity at Stations 3 ranged from $0.7-0.9 \mathrm{~m} / \mathrm{s}$. Overall, Stations 3 and 4 had slower current velocities than Stations 1 and 2.

Furthermore, the TSS results ranged from 11 to 46 $\mathrm{mg} / \mathrm{L}(11-46 \mathrm{mg} / \mathrm{L}$ and 19-29 $\mathrm{mg} / \mathrm{L}$ at Station 1 and 2, and 19-33 $\mathrm{mg} / \mathrm{L}$ and $12-15 \mathrm{mg} / \mathrm{L}$ at Station 3 and 4 ). The high TSS results at week three were due to the flood occurring during the measurement time. On average, Station 3 had the highest TSS. As for the dissolved oxygen (DO) results, the levels ranged from 4.4-5.1 mg/L. At Stations 1 and 2, the dissolved oxygen results ranged from $4.4-5 \mathrm{mg} / \mathrm{L}$ and 4.7-5.1 mg/L, respectively. Meanwhile, at Stations 3 and 4, the dissolved oxygen results ranged from 4.6-4.7 $\mathrm{mg} / \mathrm{L}$ and 3.6-3.8 mg/L, respectively.

Moreover, the $\mathrm{pH}$ results ranged from 7.31 to 7.6. Slightly different $\mathrm{pH}$ results were obtained at each station. At Station 1, the $\mathrm{pH}$ ranged from 7.31-7.58 and, at Station 2 , the $\mathrm{pH}$ results were between 7.34-7.55. At Stations 3 and 4 , the $\mathrm{pH}$ ranged from 7.31-7.55 and 7.52-7.6, respectively. These results indicated that the $\mathrm{pH}$ increased from the first to the third week and was relatively unstable. In terms of unionized ammonia $\left(\mathrm{NH}_{3}\right)$, the levels ranged from 0.043 to $0.246 \mathrm{mg} / \mathrm{L}$. The unionized ammonia at Stations 1 and 2 ranged from $0.081-0.169 \mathrm{mg} / \mathrm{L}$ and $0.043-0.115 \mathrm{mg} / \mathrm{L}$. Meanwhile, the unionized ammonia at Stations 3 and 4 ranged from $0.057-0.214 \mathrm{mg} / \mathrm{L}$ and $0.186-0.246 \mathrm{mg} / \mathrm{L}$.

\section{Hematological properties of Badher fish}

The erythrocytes of the Badher fish (Barbonymus altus) from the four stations had an average number of $1,515,2777$ cells $/ \mathrm{mm}^{3}$. The range of red blood cell was $1,400,000-2,940,000$ cells $/ \mathrm{mm}^{3}$ at Station 1 and 1,380,000$2,500,000$ cells $/ \mathrm{mm}^{3}$ at Station 2. Meanwhile, the numbers 
of blood cells at Stations 3 and 4 ranged from 1,190,000$2,210,000$ cells $/ \mathrm{mm}^{3}$ and $800,000-980,000$ cells $/ \mathrm{mm}^{3}$.

The leukocytes of the Badher fish (Barbonymus altus) from the four stations had an average number of 122,591 cells $/ \mathrm{mm}^{3}$. The number of leukocytes ranged from $69,525-$ 106,450 cells $/ \mathrm{mm}^{3}$ at Station 1 and $89,880-112,300$ cells $/ \mathrm{mm}^{3}$ at Station 2. Meanwhile, the numbers of leukocytes of the Badher fish at Stations 3 and 4 ranged from $112,250-133,500$ cells $/ \mathrm{mm}^{3}$ and $152,500-199,500$ cells $/ \mathrm{mm}^{3}$.

The hemoglobin results of the Badher fish (Barbonymus altus) from the four stations had an average value of $6.6 \mathrm{G} \%$. The range of hemoglobin values was 7-8 G\% at Stations 1 and 2. Meanwhile, at Stations 3 and 4, the hemoglobin values ranged from 6-7.5 G\% and 4.3-4.9 G\%.
The hematocrit of Badher fish (Barbonymus altus) at week one at the four stations had an average value of $27 \%$. The analysis showed a range of hematocrit at $22-30 \%$ at Station 1 and $20-25 \%$ at Stations 2 and 3. Meanwhile, the results of the hematocrit calculation at Station 4 ranged from $15-19 \%$.

The micronuclei calculation of Badher fish (Barbonymus altus) at the four stations showed different results each week. At Station 1, it was 24-34 cells/1000 at week one to three. Meanwhile, at Stations 2 and 3, the micronuclei results ranged from $28-43$ cells/1000 and 3444 cells/1000. The highest micronuclei results came from Station 4 with a range of $55-72$ cells/1000.
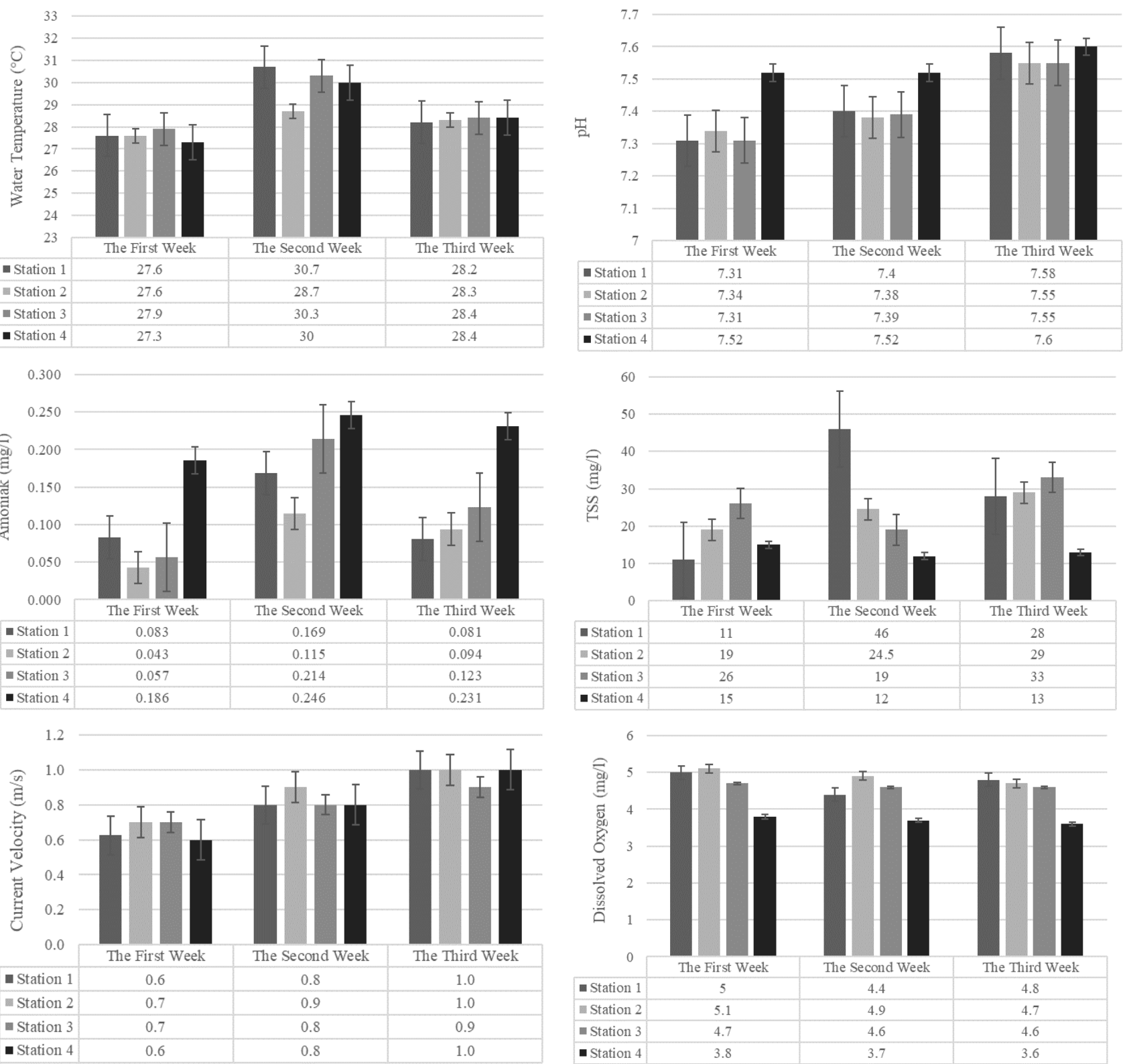

Figure 2. Water quality measurement results (Temperature, $\mathrm{pH}$, Dissolved Oxygen, Total Suspended Solid, $\mathrm{NH}_{3}$, and $\mathrm{Current}$ Velocity) in the Brantas River, Badher Bank Conservation Area, Tawangrejo Village, Binangun Sub-district, Blitar District, East Java, Indonesia 

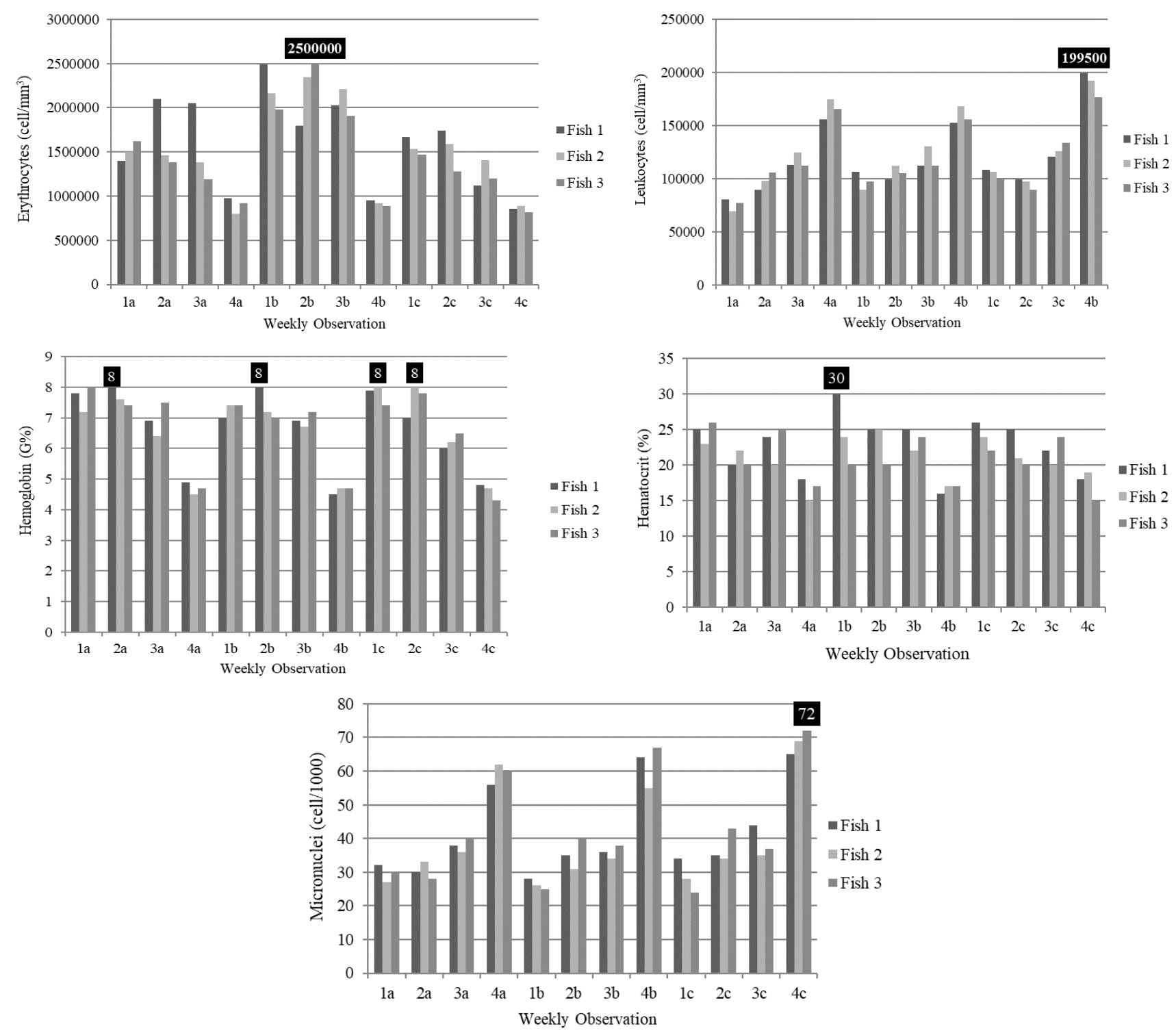

Figure 3. Result of Badher fish hematological profile (erythrocyte, leukocyte, hemoglobin, hematocrit, and micronuclei)

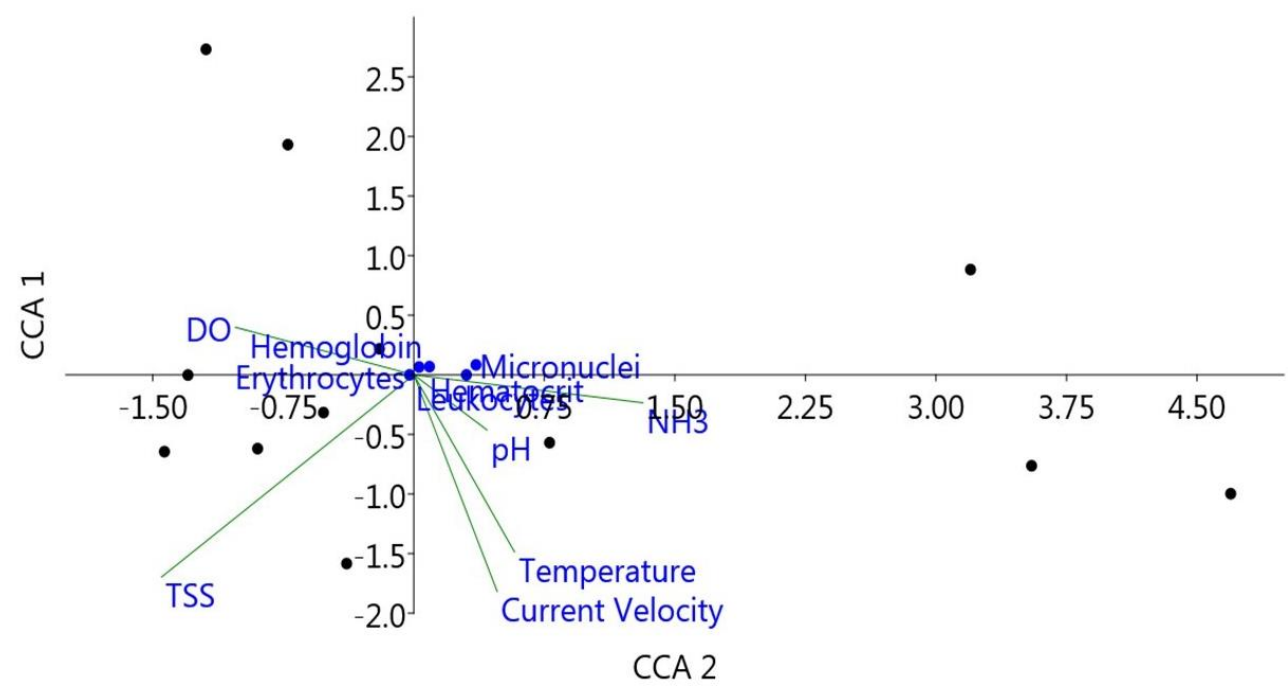

Figure 4. Result of CCA (Canonical Correspondence Analysis) between water quality and Badher fish hematological profile 


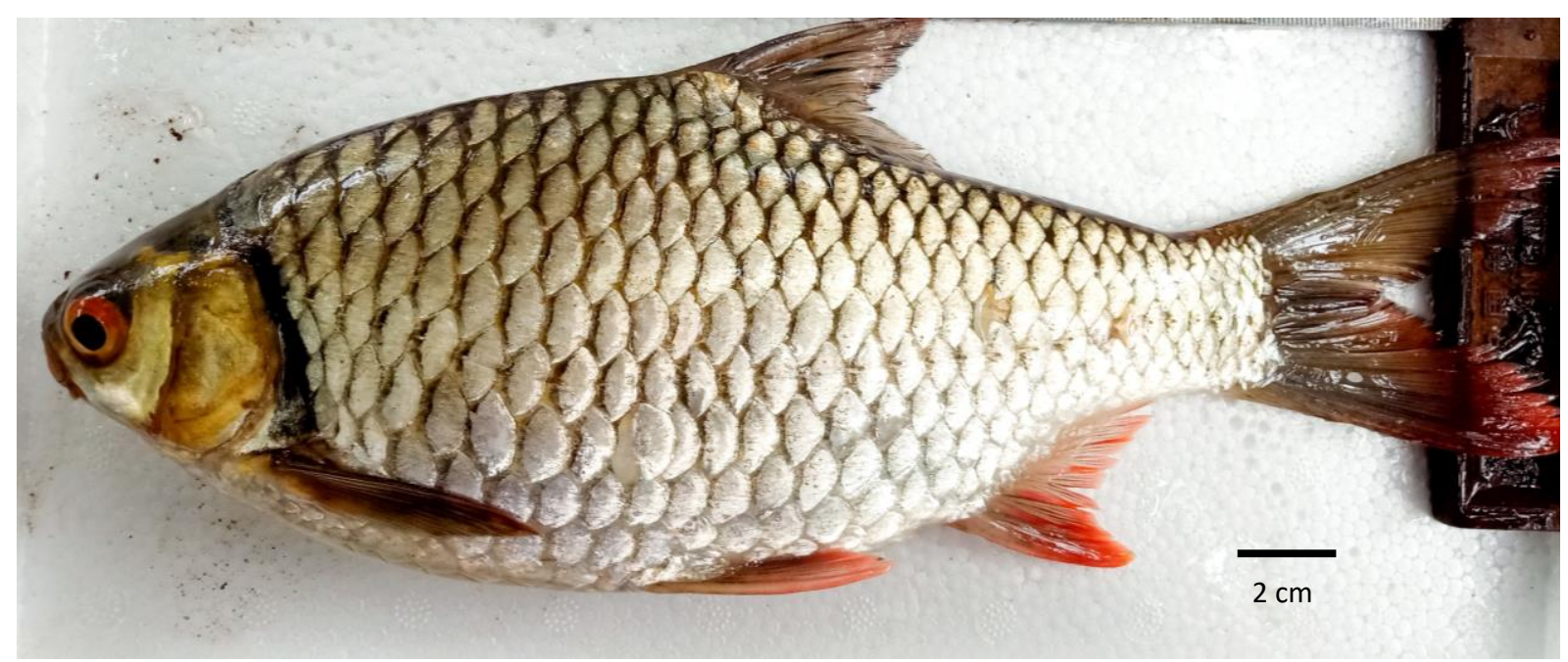

Figure 5. Badher fish (Barbonymus altus) collected from Brantas River, Badher Bank Conservation Area, Tawangrejo Village, Binangun Sub-district, Blitar District, East Java, Indonesia

\section{Relation of water quality and hematological properties}

The CCA results, as presented in Figure 3, can be interpreted as follows: (i) Because the value of erythrocytes, hemoglobin, and hematocrit tended to fall at the center of all water quality variables, they could be said to associate with temperature, current velocity, and total suspended solids (TSS), pH, dissolved oxygen (DO), and ammonia with a moderate concentration; (ii) Hematocrit and micronuclei were also associated with temperature, current, $\mathrm{pH}$, and unionized ammonia with a moderate to a high concentration. It was also correlated with TSS and DO, which tended to be low-concentrated.

\section{Discussion}

Based on Figure 2, the water quality of the Brantas River in the Badher Bank Conservation Area can be classified as normal. The increasing temperature occurred at the second week of measurement for all stations, and there was relatively no difference between Stations 1-4. So, it is considered normal. The temperature in the first and third week was lower than that in the second week because the weather was cloudy. Meanwhile, in the second week, the weather was hot. According to Łaszewski (2016), the water temperature can change at any time because it is influenced by geographical conditions, especially climatic conditions, hydrological regimes, and land use. Temperature can affect various aquatic organisms' activities, such as respiration, feed consumption, growth, and reproduction. The optimum temperature for the growth of freshwater fish is between $27-30^{\circ} \mathrm{C}$, with the best for growth is at $29^{\circ} \mathrm{C}$ (Tang et al. 2017).

Moreover, in terms of current velocity, Stations 3 and 4 had a slower current velocity than Stations 1 and 2. The slow current velocity in Station 3 happened because it is located after a river bend and has deeper water. In contrast, Station 4 is located at the confluence of two water streams, namely the Brantas River and the sugar factory's waste disposal line. According to Puteri et al. (2019), the current velocity is influenced by topography such as river bend and the depth of water; it has a slow current velocity due to the increase of sediment at the river bend area. Shallow water increases the current velocity. The study took place during the rainy season; thus, rainwater caused high current velocity in the conservation area (Ratih et al. 2015; Neno et al. 2016; Buwono et al. 2017). The water flow velocity has a vital role in distributing nutrients and sediment that fast current can carry more nutrients with optimum dissolved oxygen (Zhang et al. 2016; Suwandana et al. 2018).

On the other hand, suspended solids could affect water turbidity. Total Suspended Solid (TSS) represents the total amount of organic and inorganic particles floating in water currents, identical with water pollution (micropollutants and heavy metals) and primary production because high TSS can reduce the penetration of light entering the waters to cover water bodies (Guimarães et al. 2019). The high TSS at the third week was due to the flood occurring at the time of water measurement. The high number of TSS was typical in the rainy season; it caused the increasing erosion rate and proved that the sediment was running down into the river bodies (Paryono et al. 2017). On average, Station 3 had the highest amount of TSS. Referring to Government Regulation Number 82 of 2001, the maximum amount of TSS allowed for class II-water quality is $50 \mathrm{mg} / \mathrm{L}$. Meanwhile, the amount of TSS in the Badher Bank Conservation Area was still in the range of 11-46 mg/L. Thus, it still meets the quality standard for class II-water quality and would not harm aquatic organisms' condition.

Dissolved Oxygen (DO) is necessary for aquatic organisms because it helps respiration and osmoregulation. Differences in the amount of DO between stations were caused by temperature, high and low organic matter levels, and land cover to water surfaces (Patty et al. 2015). The amount of DO measured at Station 4 was at a low level. But, it had relatively same fluctuations in every week. Based on Government Regulation Number 82 of 2001, the standard quality value of dissolved oxygen must be $\geq$ four (4) ppm. If it is less than the expected value, it will affect the survival rate of aquatic organisms. The dissolved 
oxygen in the Badher Bank Conservation Area at Stations 1, 2, and 3 was still normal. However, the result obtained from Station 4 was below the DO threshold. It was because waste disposal came out from the river streamline of the sugar factory.

The water $\mathrm{pH}$ parameter increased from the first to the third week of measurement and was relatively unfluctuating. According to Hastuti et al. (2016), high pH values caused by ammonia cannot be ionized and become toxic (unionized ammonia). Based on Government Regulation No. 82 of 2001, the permissible pH values for aquatic organism life and class II-water quality range from 6-9. According to Emilia and Mutiara (2019), ammonia is correlated with $\mathrm{pH}$. At low $\mathrm{pH}$ conditions, ammonia can ionize and then turn into ammonium.

Meanwhile, in alkaline conditions, ammonia cannot be ionized and becomes toxic (unionized ammonia). The amount of ammonia in the second week was high because the paddy fields' runoff was relatively high. Inland agriculture uses relatively high urea and seeps through the soil into the river bodies in the form of runoff (Azizah and Humairoh 2015). On average, Station 4 had high unionized ammonia due to inputs from Stations 1, 2, and 3 and the sugar factory's waste disposal streamline. According to Windusari and Sari (2015), the high concentration of unionized ammonia in river water can cause the death of the aquatic organism. Unionized ammonia is dangerous if it reaches a high concentration because it can reduce dissolved oxygen (DO) due to unionized ammonia dissociation. The high level of unionized ammonia can also disrupt the hemoglobin function. Based on Government Regulation No. 82 of 2001, unionized ammonia levels have a threshold of $0.02 \mathrm{mg} / \mathrm{L}$. Findings suggest that waters in the Badher Bank Conservation Area are lightly polluted. The pollution was most likely due to discharge from paddy fields near the research area and the sugar factory's wastewater.

Erythrocytes are the main factor and reliable indicator in identifying various sources of stress in aquatic organisms because toxins can directly affect the oxygen transport system in the tissues (Ariweriokuma et al. 2016; Atli et al. 2016). The number of erythrocytes in Badher fish showed that fish from Station 4 had the lowest erythrocytes $\left(800,000-980,000\right.$ cells $\left./ \mathrm{mm}^{3}\right)$. The standard number of erythrocytes was between $1.05 \times 106$ cells $/ \mathrm{mm}^{3}$ and $3.0 \mathrm{x}$ 106 cells $/ \mathrm{mm}^{3}$, depending on the type of fish and environmental influencing factors. The number of Badher fish erythrocytes at Stations 1, 2, and 3 was normal. But, at Station 4, the number of erythrocytes was below the threshold, most likely due to the sugar factory's waste disposal. A decrease in hemoglobin and erythrocyte values represents the impact of toxins and pathological processes on organisms (Ambo et al. 2015).

Unlike erythrocytes, several stress factors can cause changes in the number of white blood cells, and all types of leukocytes play an essential role in the immune system (Tulgar and Celik 2015). Changes in the number of leukocytes are an excellent indicator of environmental stressors due to the immune response to toxins (Odo et al. 2017). Based on the data listed in figure 3 , there was an increase in white blood cells at each station, in which fish at Station 1 showed a lower increase than those in Station 2. Meanwhile, fish at Station 2 showed a lower increase than those in Station 3, and fish at Station 3 showed a lower increase than those in Station 4. In summary, fish at Station 1, 2, and 3showed normal limits of leukocytes, while fish at Station 4 showed leukocytes exceeding the threshold due to the sugar factory's waste disposal. A significant increase in white blood cells indicates an increase in antibody production to help fish survive and fight toxins as a form of immunological reaction (Vaiyanan et al. 2015).

Hemoglobin has a function in the process of transporting oxygen and carbon dioxide in erythrocytes (Susandi et al. 2017). The results showed that the hemoglobin level in Badher fish in this research was normal, not exceeding or less than the limit. However, the amount of hemoglobin at Station 4 was below the average. A low level of hemoglobin causes a low amount of oxygen in the blood. According to Sreelekshmy dan Miranda (2016), hemoglobin concentration reflects the oxygen supply condition in organisms and how these organisms can manage it as best as possible to remain stable. A decrease in hemoglobin concentration due to industrial waste can cause fish to experience a reduction in oxygen supply to tissues and cause decreased physical activities of the fish. The research shows that at Station 4, hemoglobin level was below the average, so it can be ascertained that pollution was happening by the sugar factory's wastewater or the input of unionized ammonia from the paddy fields. Similarly, the number of erythrocytes at Station 4 was below average, or degradation occurred. Kefas et al. (2015) state that a decrease in hemoglobin levels is caused by damage. A decline in the number of erythrocytes is caused by the pathological conditions of fish exposed to toxins.

Hematocrit is a hematological and biochemical parameter that is very important in evaluating fish health, especially related to anoxia and moderate hypoxia (Sula et al. 2020). Hematocrit is also an excellent indicator to see the level of blood cell damage due to infection (Triki et al. 2016). The hematocrit value in fish below or less than $30 \%$ indicates erythrocyte deficiency (Putra 2015). Hematocrit at Stations 1, 2, and 3 was classified as safe, while at Station 4, it was below the threshold due to waste disposal of the sugar factory. Changes in hematocrit values describe the physiological pressure on fish or the carrying capacity of oxygen in the blood (Idzin et al. 2018). This statement is relevant to the amount of the low erythrocytes at Station 4, showing the presence of infection and erythrocyte damage.

Besides hemoglobin and hematocrit measurement, micronuclei testing is a solid indicator to monitor the presence of genotoxic agents causing genetic mutations in fish due to pollutants and toxic substances in the aquatic environment (Tasneem and Yasmeen 2018). In this research, Station 4 showed a high micronuclei number (5572 cells/1000) in Badher fish due to the household, agriculture, and factory's waste disposal around the conservation area. According to Hussain et al. (2018), river waters with a polluted state show a high frequency for single micronuclei induction of 50 cells/1000. Disposal of 
treated and untreated waste in waters impacts environmental health and the organisms. Micronuclei existed in fish living in the polluted water environment. The increasing number of micronuclei represented the irregularities of number and structural chromosomal produced by the various agents in cells, this condition can cause potential cytotoxic effects of metals and genotoxic agents on the body of organisms (Arslan and Parlak 2017).

The CCA (Canonical Correspondence Analysis) method was carried out based on water quality parameters and Badher fish hematological profiles to ensure the correlation between the two parameters. CCA analysis was performed to analyze the effect of water quality as environmental parameters (independent variables) on the conditions of the hematological parameters (dependent variables), it clearly illustrated on the two axes of the diagram (Wang and $\mathrm{Yu}$ 2017). The line length of the environmental parameter indicates the correlation strength, and the line direction shows its correlation with the dependent variable. The environmental parameters located in the same direction as the dependent variable have a positive correlation and vice versa (Silambarasan et al 2016). The analysis suggested that erythrocytes, leucocytes, and hemoglobin were associated with all water quality parameters (DO, TSS, temperature, $\mathrm{pH}$, current velocity, and unionized ammonia) at moderate concentrations since they were at the midpoint of the $\mathrm{x}$ and $\mathrm{y}$ axes. These results indicate that all parameters are bad enough.

Based on CCA analysis, micronuclei and hematocrit parameters were associated with $\mathrm{pH}$, unionized ammonia, temperature, and current velocity at high concentrations, while DO and TSS at low concentrations. The CCA analysis indicated that $\mathrm{pH}$, unionized ammonia, temperature, and current velocity significantly affect the micronuclei and hematocrit conditions. Meanwhile, DO, and TSS affected the micronuclei and hematocrit conditions when the two were in low concentration, considering that both are closely related to oxygen supplies. According to Al-Zahaby et al. (2017), if the living environment of the fish being exposed to highconcentration of unionized ammonia and several environmental parameters that directly affect the hematological conditions of the fish, such as $\mathrm{DO}, \mathrm{pH}$, and temperature, it will decrease the total number of erythrocytes, hemoglobin, and hematocrit.

Based on the analysis, it can be concluded that the water condition of the Badher Bank Conservation Area was classified as normal at Stations 1-3 and polluted at Station 4. The pollution classification was based on the results of water quality parameters and hematological profiles of Badher fish below the threshold. Low DO and high unionized ammonia degenerated the hematological profiles of Badher fish. Degeneration disturbs the oxygen transport system (low hemoglobin and hematocrit below 30\%). As such, the number of leukocytes increased as a form of resistance to toxicants or immunological responses. Also, micronuclei, an indicator of a genotoxic agent, was high enough, indicating a toxic substance entering the fish body. $\mathrm{pH}$, DO, temperature, TSS, unionized ammonia, and current velocity at high concentrations significantly affected leucocytes, erythrocytes, and hemoglobin. In contrast, DO and TSS influenced when both were in low concentration.

\section{ACKNOWLEDGEMENTS}

This research was funded by DPP SPP FPIK UB< Malang, Indonesia led by Dr. Asus Maizar Suryanto Hertika. Our gratitude goes to Pokmaswas Fajar Bengawan, as the Badher Bank Conservation Area Manager, for their assistance during the research process.

\section{REFERENCES}

Al-Zahaby MA, Shalaby AM, Abd-El-Rahman GF, Ayyat MSA. 2017. Impact of water quality on the blood parameters of Nile Tilapia in different fish farms. Zagazig J Agric Res 44 (2): 571-581. DOI: 10.21608/zjar.2017.53875.

Ambo EE, Bassey SO, Iyam MA, Inah GM, Uwalaka SU. 2015. Effect of Cypermetrin on the haematological indices of African Catfish (Clarias gariepinus). J Biopestic Environ 2 (1-2): 29-35.

Arfiati D, Hertika AMS, Lukito DA. 2020. Haematology profile in silver barb (Barbonymus Gonionotus) caught from Jagir River, Surabaya City, East Java, Indonesia. IOP Conf Ser Earth Environ Sci 416: 012008. DOI:10.1088/1755-1315/416/1/012008.

Ariweriokuma SV, Gabriel UU, Deekae SN, Akinrotimi OA. 2016. Haematological characteristics of African Catfish (Clarias gariepinus) fed dietary inclusion levels of green leaf (Amaranthus cruentus). Intl J Innovative Stud Aquat Biol Fish 2: 11-22.

Arslan OC, Parlak H. 2017. Micronucleus test good biomarker for determination of genetic changes in aquatic organism. Aquat Pollut Toxicol 1 (3): 1-5.

Atli G, Canli EG, Eroglu A, Dogan Z. 2016. Cadmium and lead alter the antioxidant and osmoregulation systems in the erythrocyte of fish (Oreochromis niloticus). Turkish J Fish Aquat Sci 16: 361-369. DOI: 10.4194/1303-2712-v16_2_16.

Azizah M, Humairoh M. 2015. Analisis kadar amonia $\left(\mathrm{NH}_{3}\right)$ dalam air Sungai Cileungsi. Jurnal Nusa Sylva 15 (1): 47-54.

Badan Informasi Geospasial Indonesia. 2021. Peta Indonesia. https://tanahair.indonesia.go.id/portal-web/inageoportal/\#/ [Indonesian]

Badan Standarisasi Nasional (BSN). 2004. SNI 06-6989.3-2004 Air dan Air Limbah-Bagian 3: Cara Uji Padatan Tersuspesi Total (Total Suspended Solid, TSS) secara Gravimetri. Badan Standarisasi Nasional, Jakarta. [Indonesian]

Badan Standarisasi Nasional (BSN). 2005. SNI 19-7119.1-2005 Air dan Air Limbah-Bagian 1: Cara Uji kadar Amoniak $\left(\mathrm{NH}_{3}\right)$ Dengan Metoda Indofenol Menggunakan Spektrofotometer. Badan Standarisasi Nasional, Jakarta. [Indonesian]

Badan Standarisasi Nasional (BSN). 2015. SNI 8066:2015 Tata Cara Pengukuran Debit Aliran Sungai dan Saluran Terbuka Menggunakan Alat Ukur Arus dan Pelampung. Badan Standarisasi Nasional, Jakarta. [Indonesian]

Buwono NR, Fariedah F, Anestyaningrum RE. 2017. Komunitas ikan di Sungai Jerowan Kabupaten Madiun. J Aquac Fish Health 6 (2): 8187. DOI: $10.20473 /$ jafh.v6i2.11284

Emilia I, Mutiara D. 2019. Parameter fisika, kimia dan bakteriologi air minum alkali terionisasi yang diproduksi mesin kangen water LeveLuk SD 501. Sainmatika 16 (1): 67-73. DOI: 10.31851/sainmatika.v16i1.2845. [Indonesian]

Guimarães TT, Brum D, Veronez MR, Koste EC, Souza EM, Gonzaga JL, Mauad FF. 2019. Evaluation of regression analysis and neural networks to predict total suspended solids in water bodies from unmanned aerial vehicle images. Sustainability 11 (9): 1-13. DOI: 10.3390/su11092580.

Haryono, Rahardjo MF, Affandi R, Mulyadi. 2017. Karakteristik morfologi dan habitat ikan Brek (Barbonymus balleroides Val. 1842) 
di Sungai Serayu Jawa Tengah. Jurnal Biologi Indonesia 13: 223-232. DOI: 10.14203/jbi.v13i2.3396. [Indonesian]

Hastuti YP, Nadeak H, Affandi R, Faturrohman K. 2016. Penentuan pH optimum untuk pertumbuhan kepiting bakau Scylla serrata dalam wadah terkontrol. Jurnal Akuakultur Indonesia 15 (2): 171-179. DOI: 10.19027/jai.15.2.171-179. [Indonesian]

Hussain B, Sultana T, Sultana S, Masoud MS, Ahmed Z, Mahboob S. 2018. Fish eco-genotoxicology: Comet and micronucleus assay in fisherythrocytes as in situ biomarker of freshwater pollution. Saudi J Biol Sci 25: 393-398. DOI: 10.1016/j.sjbs.2017.11.048

Idzin SA, Junardi, Rousdy RW. 2018. Kadar hematokrit dan hemoglobin ikan sapu-sapu (Pterygoplichthys pardalis) terpapar logam berat merkuri klorida. Protobiont 7 (3): 68-71. DOI: 10.26418/protobiont.v7i3.29085. [Indonesian]

Jariyah NA. 2019. Evaluasi kinerja sosial ekonomi DAS Brantas berdasarkan penerapan P61/Menhut-II/2014. Jurnal Penelitian Sosial $\begin{array}{lll}\text { dan Ekonomi Kehutanan } 16 & \text { (2): 95-113. DOI: }\end{array}$ 10.20886/jpsek.2019.16.2.95-113

JiaXin J, Ying W, Hong J, Yan K, XueHe L, Xiu Ying Z. 2016. Improvement of ecological geographic regionalization based on remote sensing and canonical correspondence analysis: A case study in China. Sci China Earth Sci 59 (9): 1745-1753. DOI: 10.1007/s11430-016-5297-5

Kefas M, Abubakar KA, Ja'afaru A. 2015. Haematological indices of tilapia (Oreochromis niloticus) from Lake Geriyo, Yola, Adamawa State, Nigeria. Intl J Fish Aquat Stud 3 (1): 9-14.

Keputusan Menteri Pekerjaan Umum Republik Indonesia Nomor: 268/KPTS/M/2010 Tentang Pola Pengelolaan Sumber Daya Air Wilayah Sungai Brantas (Decree of the Minister of Public Works and Housing Number 268 of 2010). [Indonesian]

Łaszewski M. 2016. Summer water temperature of lowland Mazovian rivers in the context of fisheries management. Archieve of Pol Fish 24 (1): 3-13. DOI: 10.1515/aopf-2016-0001

Lestari E, Setyawati TR, Yanti AH. 2017. Profil hematologi ikan gabus (Channa Striata Bloch, 1793). Protobiont 6 (3): 283-289. DOI 10.26418/protobiont.v6i3.22495

Naqvi GZ, Shoaib N, Ali AM. 2016. Genotoxic potential of pesticides in the peripheral blood erythrocytes of fish (Oreochromis mossambicus). Pakistan J Zool 48 (6): 1643-1648.

Neno AK, Herijanto H, Wahid A. 2016. Hubungan debit air dan tinggi muka air di Sungai Lambagu Kecamatan Tawaeli Kota Palu. Warta Rimba 4 (2): 1-8. [Indonesian]

Nwani CD, Nwadinigwe AO, Joshua PE, Onyeke CC, Ogbonna SU, Ukonze JA, Eze SOO. 2016. Hepatic antioxidant status and hematological parameters in African Catfish, Clarias Gariepinus juvenile exposed to sublethal concentration of Psychotria Microphylla. Anim Plant Sci 26 (1): 275-281.

Odo GE, Agwu JE, Ivoke N, Ejere VC, Atama CI, Ezea CO, Aguoru GC, Anya BC. 2017. Effect of short term exposure to cyperdicot on behavioural and haematological responses in African Catfish Clarias Gariepinus. Turkish J Fish Aquat Sci 17 (1): 61-70. DOI 10.4194/1303-2712-v17_1_08.

Olasoji SO, Oyewole NO, Abiola B, Edokpayi JN. 2019. Water quality assessment of surface and groundwater sources using a water quality index method: A case study of a peri-urban town in Southwest, Nigeria. Environments 6: 1-11. DOI: 10.3390/environments6020023

Paryono P, Damar A, Susilo SB, Dahuri R, Suseno H. 2017. Sedimentasi delta Sungai Citarum, Kecamatan Muara Gembong, Kabupaten Bekasi. Jurnal Penelitian Pengelolaan Daerah Aliran Sungai 1 (1): 1526. DOI: 10.20886/jppdas.2017.1.1.15-26. [Indonesian]

Patty SI, Arfah H, Abdul MS. 2015. Zat hara (fosfat, nitrat), oksigen terlarut dan $\mathrm{pH}$ kaitannya dengan kesuburan di Perairan Jikumerasa, Pulau Buru. Jurnal Pesisir dan Laut Tropis 3 (1): 43-50. DOI: 10.35800/jplt.3.1.2015.9578. [Indonesian]

Pawar PV, Bhilave MP. 2019. Effect of insecticide Chlorantraniliprole on hematological profile of fingerlings of freshwater fish Cirrhinus Mrigala. Intl J Res Anal Rev 6: 982-989.

Peraturan Pemerintah Republik Indonesia Nomor 82 Tentang Pengelolaan Kualitas Air dan Pengendalian Pencemaran Air (Governmen Regulation Number 82 of 2001 concerning Water Quality Management and Water Pollution Control). [Indonesian]

Priya KK, Ramesh M, Saravanan M, Ponpandian N. 2015. Ecological risk assessment of silicon dioxide nanoparticles in a freshwater fish Labeo rohita: Hematology, ionoregulation and gill $\mathrm{Nap} / \mathrm{Kp}$ ATPase activity.
Ecotoxicol Environ Saf 120: 295-302. DOI: 10.1016/j.ecoenv.2015.05.032

Puteri MFD, Putra YS, Adriat R. 2019. Penentuan debit aliran di muara Sungai Pawan Kabupaten Ketapang berdasarkan parameter kecepatan arus dan kedalaman sungai. Prisma Fisika 7 (3): 326-330. DOI: 10.26418/pf.v7i3.38939. [Indonesian]

Putra AN. 2015. Gambaran darah Ikan Patin (Pangasius Sp.) dengan penambahan probiotik pada pakan. Jurnal Ilmu Pertanian dan Perikanan 4 (1): 63-69. [Indonesian]

Ratih I, Prihanta W, Susetyarini RE. 2015. Inventarisasi keanekaragaman makrozoobentos di daerah aliran sungai Brantas Kecamatan Ngroro Mojokerto sebagai sumber belajar biologis SMA kelas X. Jurnal Pendidikan Biologi Indonesia 1 (2): 158-169. DOI: 10.22219/jpbi.v1i2.3327. [Indonesian]

Silambarasan A, Sivaraj S, Muthuvelu S, Bharathidasan V, Murugesan P. 2016. Influence of environmental parameters on abundance and diversity of phytoplankton in Pichavaram mangroves, southeast coast of India. Indian J Geo-Mar Sci 45 (4): 591-602.

Solleh BI, Zafar T, Shammi QJ. 2015. Impact of sub-lethal concentration of diazinon on haematological profile of Channa striatus (Bloch). Online Brasileiro 5: 125-128.

Sreelekshmy SG, Miranda MTP. 2016. Impact of industrial effluent on the haematological profile in marine catfish, Arius nenga. International J Res Fish Aquac 6: 4-7.

Sula E, Aliko V, Barcel' B, Faggio C. 2020. Combined effects of moderate hypoxia, pesticides and PCBs upon crucian carp fish, Carassius carassius, from a freshwater lake-in situ ecophysiological approach. Aquat Toxicol 228: 1-11. DOI: 10.1016/j.aquatox.2020.105644

Susandi F, Mulyana, Rosmawati. 2017. Peningkatan imunitas benih ikan gurame (Osphronemus Gouramy Lac.) terhadap bakteri aeromonas hydrophila menggunakan rosella (Hibiscus Sabdariffa L.). Mina Sains 3 (2): 1-13. DOI: $10.30997 / \mathrm{jms} . v 3 \mathrm{i} 2.889$

Suwandana AF, Purnomo PW, Rudiyanti S. 2018. Analisis perbandingan fitoplankton dan zooplankton serta TSI (Trophic Saprobic Index) pada perairan tambak di Kampung Tambak lorok Semarang. Maquares 7 (3): 237-243. [Indonesian]

Tang UM, Muchlisin ZA, Syawal H, Masjudi H. 2017. Effect of water temperature on the physiological stress and growth performance of tapah (Wallago leeri) during domestication. Archieve Pol Fish 25: 165-171. DOI: 10.1515/aopf-2017-0016

Tasneem S, Yasmeen R. 2018. Induction of micronuclei and erythrocytic nuclear abnormalities in peripheral blood of fish Cyprinus carpio on exposure to karanjin. Iranian J Toxicol 12 (2): 37-43. DOI: 10.29252/arakmu.12.2.37

Triki Z, Grutter AS, Bshary R, Ros AF. 2016. Effects of short-term exposure to ectoparasites on fish cortisol and hematocrit levels. Mar Biol 163 (9): 1-6. DOI: 10.1007/s00227-016-2959-y

Tulgar A, Celik ES. 2015. Effects of sublethal concentrations of propargite to white blood cells of common carp (Cyprinus carpio, Linnaeus, 1758). Mar Sci Technol Bull 4 (1): 13-17.

Undang-Undang Republik Indonesia Nomor 5 Tahun 1990 Tentang Konservasi Sumber Daya Alam Hayati dan Ekosistemnya. [Indonesian]

Vaiyanan V, Sridharan G, Raveendran S, Chairman K. 2015. Impact of pesticide on haematological parameters of Cyprinus Carpio. World J Pharm Pharm Sci 4: 1424-1430.

Wang Z, Yu H. 2017. Canonical correspondence analysis of phytoplankton community and environmental factors in Genhe River. Asian Agric Res 9: 24-27. DOI: 10.22004/ag.econ.267658

Windusari Y, Sari NP. 2015. Kualitas perairan Sungai Musi di Kota Palembang Sumatera Selatan. Bioeksperimen 1: 1-5. DOI: 10.23917/bioeksperimen.v1i1.309. [Indonesian]

Yaji A, Iheanacho S, Ogueji E. 2018. Sublethal exposure and toxicity effect of propanil on hematology and serum biochemistry in Oreochromis niloticus in a static bioassay. Gazi University J Sci 31 (4): 1048-1062.

Yüce AM, Gönülol A. 2016. Evaluation of the relationship between epiphytic diatoms and environmental parameters with the Canonical Correspondence Analysis (CCA). Pakistan J Bot 48 (4): 1723-1730.

Zhang X, Zhang Y, Ji Y, Zhang Y, Yang Z. 2016. Shoreline change of the Northern Yellow River (Huanghe) delta after the latest deltaic course shift in 1976 and its influence factors. Coastal Research 74: 48-58. DOI: 10.2112/SI74-005.1. 